\title{
Integrated Communication as a Marketing Instrument in the Economy and Pharmaceutical Industry
}

M. Hosseini (Mohammad Hosseini)

Pharmacists of Triangulum Pharmacy, SEUC PhD Program in Health

Management and Public Health. Dreieich, Germany.

\section{E-mail address:}

mh26041980@gmail.com

\section{Reprint address:}

Mohammad Hosseini

Pharmacists of Triangulum Pharmacy

SEUC PhD Program in Health Management and Public Health

Frankfurter Str. 3763303

Dreieich

Germany

Source: Clinical Social Work and Health Intervention

Volume: 11

Issue: 4

Pages: $23-27$

Cited references: 16

\section{Reviewers:}

Michael Costello

University of Scranton School of Education, USA

Eric Kalavsky

IGAP Vienna, Austria

\section{Keywords:}

Communication. Pharmacies. Digital Changes.

\section{Publisher:}

International Society of Applied Preventive Medicine i-gap

CSWHI 2020; 11(4): 23 - 27; DOI: 10.22359/cswhi_11_4_03 (C) Clinical Social Work and Health Intervention

\section{Abstract:}

Communication between people always takes place on a cognitive level. The processes of information processing, internal and external situations and social interaction are among the essential characteristics of communication. How does a pharmacy affect the customer? How is the pharmacy perceived externally? The question here is: If communication is less effective on a verbal level than on a presentation level. 


\section{Introduction}

Globalization, digitalization and demographic change are leading to increasing competitive pressure for pharmacies. This is also intensified not least by competition in communication between them. It is therefore not surprising that more and more companies are using unusual communication concepts in order to bind customers whose attention, processing and perception capacities are limited. Corporate communication is thus becoming increasingly important in order to survive in saturated markets ${ }^{1}$. Communication between people always takes place on a cognitive level. The processes of information processing, internal and external situations and social interaction are among the essential characteristics of communication $^{2}$. Nevertheless, there is no generally valid definition for the term, because communication is understood to be primarily actions that are interpreted differently depending on the situation, the means of communication and the person. If the term communication is derived from the French and English ,comuniquer" and „to communicate“, its meaning can be translated as „to communicate" or "Communication“. The two terms „converse“ and „conversation" form the opposite. These always indicate an exchange of information between people. According to this view, communication would therefore be one-sided, because in this case the sender would communicate and the receiver would merely listen, which in turn would not indicate a pure information exchange. However, communication means more: the purpose of communication is to encourage people to enter into a mutual exchange of realities and images and, in addition, to inform the respective recipient $^{3}$. This is done through different communication channels. The media landscape, for example, has undergone major changes in recent years. Classical communication channels and media such as newspapers, radio or television have been supplemented or even replaced by various social media channels such as blogs, Facebook or newsletters. It can therefore be assumed that, in addition to classic communication instruments, social media communication also has a considerable influence on corporate success. (Trusov et al. 2009). In addition, there is a constantly increasing use of social media channels, which has led to a change in the type of communication. The previous transmitter-receiver model has been replaced by the transmitter-multi-receiver model. A message is now not only transmitted from sender to receiver, but - depending on the distribution of the message - from one sender to many receivers. (Bruhn et al., 2011, p.40).

\section{Communication policies}

The communication policy (promotion), the fourth $\mathrm{P}$ in the marketing mix, deals with the exchange between customers and companies. Accordingly, external communication is directed directly to the previously defined target groups. In particular, external communication is defined as the impression made by the company from the outside: How does a pharmacy affect the customer? How is the pharmacy perceived externally? Here, communication is less effective on a verbal level than on a presentation level. On the basis of different sales channels (e.g. advertising via blog) it can then be decided which content is ultimately communicated to the outside world ${ }^{4}$. In addition to PR (public relations) and product placement, communication policy also includes sales promotion, personal sales and advertising 5 .

However, these pose challenges for integrated communication. These challenges are described by the five dimensions according to Kirchner (2006). These dimensions include ${ }^{6}$ :

- Integrated self-portrayal: Consistent self-portrayal only works if there is a clear market positioning that reflects both the values and the personality of the brand.

- Interdepartmental planning and cooperation:

\footnotetext{
${ }^{1} \mathrm{Vgl}$. Esch et al. (2009), Brand identity as a basisi fort he design of internal and external communication

${ }^{2}$ Vgl. Strohner (2006), Communication, p. 28

${ }^{3}$ Vgl. Ternes (2008), Communication - A- Key Qualification, p. 20

${ }^{4}$ See. Manweiler (2014), Impacts on the emplementation of a managment scheme p. 13

${ }^{5}$ See. Freter (1983), Market and customer segmentation: customer - oriented market design and processing. Pp. 292

${ }^{6}$ See. Integrated Business Communication, pp. 86-100
} 
Companies are complex, so integrated communication can only work if departments work together on an interdisciplinary basis.

- Customer orientation: Customer loyalty must be strengthened through holistic relationship management.

- Stakeholder-oriented integration: An integrated communication concept takes into account all relevant stakeholders, e.g. shareholders, suppliers or employees.

- Anchoring communication in pharmacies: Derivation of a communication strategy from the corporate strategy. In addition, the integrated communication also serves as an interface between the public and pharmacies as well as for obtaining feedback for the company. This dimension is particularly important so that communication can be integrated into corporate management.

Basically, therefore, ,integrated“ means nothing more than ,united“, meaning a union between personal communication and various marketing measures - from traditional radio advertising to viral marketing and social media marketing.

Online marketing is becoming increasingly important here. Since extremely short response times are required on the Internet, companies must react very quickly to inquiries. Otherwise, potential customers may quickly switch to another company with shorter response times. This is why more and more companies are now acquiring their customers via social media channels such as Facebook, Xing or Twitter. This means that brand presence on the Internet is becoming increasingly important. A good sales channel or a good advertisement for your own pharmacies is also the use of a homepage. It is not for nothing that the German management consultant Prof. Hermann Simon (2000) said:

„In marketing, the Internet is not everything, but without the Internet, everything is nothing "7

This sentence clearly shows how important online marketing now is in the overall picture of marketing. Communication must therefore also be targeted in online marketing. This goal is achieved by integrated communication, in partic- ular by using different social media strategies. The most important strategies include the Influencer strategy, which enables an active customer dialogue between the company and the customer, for example on a Facebook page or with the help of a celebrity on television. The customer dialogue creates proximity, which leads to a perceived enthusiasm among consumers or customers and is reflected in word-of-mouth propaganda. This knowledge can be implemented by the management in campaigns and leads in the long run to a better perception of the respective company ${ }^{8}$. A good example of this is the advertising of the „Ratiopharm twins" for products of the drug manufacturer Ratiopharm due to its „product diversity“. Accordingly, every campaign includes a communication concept and the more digital the world becomes, the easier communication becomes for companies. New viral campaigns enable companies to get in touch with their customers in a more targeted way and thus change not only the way they communicate, but also their own business models and corporate culture. The campaigns of the new digital world must be faster, more targeted and above all more complex in order to keep customers happy.

\section{Conclusions}

1. communication via social media can have a positive effect on a company, as in this case, but also a negative effect if it is done in an imprudent manner

2. Greenpeace skilfully focused its social media communications by using the channels specifically for campaigns against Nestlé

These actions ultimately led Nestlé to fundamentally rethink its public image and, in the meantime, to completely change its social media communication.

Another example of successful integrated communication is the „Pfizer" company with its marketing campaign on „Viagra“. The drug belongs to the group of phosphodiesterase type 5 (PDE5) inhibitors and contains the active ingredient sildenafil. Viagra is used to increase potency in men $^{9}$. The uniqueness of Pfizer and Vi-

\footnotetext{
${ }^{7}$ Simon (2000), The Great Handbook of Strategic Concepts, p. 158

${ }^{8}$ See. Esch (2014), Brand identity as a basis fort he design of internal and external communication, p. 493

${ }^{9}$ See. NetDoktor (2020), Viagra (28.02.2020), https://www.netdoktor.de/medikamente/viagra/ [28.02.2020]
} 
agra was particularly evident in 2002 with a successful integrated campaign. In this campaign, Pfizer relied on a celebrity and used an influencer strategy that did not even exist in this form at the time. Football star Pelé talked about erectile dysfunction in a TV spot, thus breaking a taboo subject. He also encouraged other men to consult a doctor if they had problems. The campaign became very popular in combination with advertisements in the public print media, response possibilities via telephone hotline as well as reply postcards and information tour with a specially designed truck ${ }^{10}$.

Integrated communication is establishing itself - as seen in the two examples - more and more as a cross-cutting function between pharmacies and customers. The new form of communication makes it easier to reach a wide range of customers and to operate on several platforms simultaneously, as well as offline. Marketing is no longer carried out via one channel only, but reaches a much larger target group through targeted placement in the respective networks than would be possible via the classic channels, such as television or radio. Integrated communication has thus become a communication factor between customer and company that should not be underestimated. The influence of social networks on people and their everyday life is constantly growing. Due to the networking of people worldwide and the ongoing globalization, social networks in particular will continue to play an important role within Internet communication. Pharmacies have to be aware of these developments and must react to them promptly.

\section{References:}

1. BRUHN M (2014) Marketing-the basisi for study and practive. (12. Auflage). Basel: Springer Verlag.

2. ESCH F R, FISCHER A (2009) Brand identity as the basis fort he design of internal and external communication. IN: Bruhn, Manfred/Esch, Franz-Rudolf, Tobias Langner (Hrsg): Handbuch Kommunikation. Wiesbaden: Gabler Verlag.

3. FRETER H (1983) Market and customer segmention: customer-oriented market acquisi- tion and processing. (2. Auflage). Stuttgart: Kohlhammer.

4. KIRCHNER K (2006) Integrated corporate communicatio. Theoretical and empirical inventory and an analysis of large American companies. Wiesbaden: Springer.

5. MANWEILER N (2014) Effects of implementing complaint management. Hamburg: DUV.

6. POGODA A (2003) You also have to sell miracles: How Viagra advertises. In: Pharma meets brand: branded technology fort he healthcare market. Munich: Urban \& Vogel Medien und Medical publishing house chaft $\mathrm{mbH} \& \mathrm{Co} . \mathrm{KG}$.

7. SIMON H (2000) The great handbook of strategy concepts: Ideas that changed the business world. Frankfurt am Main: Campus.

8. STROHNER H (2006) Communication. Cognitive basic and practical applications. Göttingen: Vandenhoeck \& Ruprecht.

9. TERNES D (2008) Communication - a key qualification: Introduction to essential areas of interpersonal communication. Paderborn: Junfermann Verlag

10. BAYONA M (2010) Kampagnen - Update 2: Nestle, Kitkat and the Palm Oil. (11.05.2010), http://www.greenpeace.de/themen/waelder/nachrichten/artikel/nestle_zoeg ert_greenpeace_bleibt_dran/ [abgefragt am 22.02.2020].

11. GABLER WIRTSCHAFTSLEXIKON (2020) Marketing. Online: https://wirtschaftslexikon.gabler.de/definition/marketing-39435 [abgefragt am 20.02.2020].

12. HERMES O (2010) A global corporation fails because of social media. (28.04.2010), http://www.absatzwirtschaft.de/Content/_p= 1003214,_b=70121, t=ft,doc_page=1 [abgefragt am 25.02.2020].

13. HEIN D (2010) PR - Debacle: Nestle turns ist own fans against itself. (22.03.2010) http:/www.horizont.net/aktuell/marketing/pa ges/protected/PR-Debakel-Nestle-bringteigeneFans-gegen-sich-auf_91027.html [abgefragt am 28.02.2020].

14. NESTLE (2010) Nestle wants to protect primeval forests afted Greenpeace campaign,

${ }^{10}$ See. Pogoda (2003), You would also like to know that you need to sell, p. 54f. 
hundreds of thousands Consumers took part in protest against Kitkat. (17. 05. 2010) http://www.presseportal.de/pm/6343/

1614608/greenpeace_e_v [abgefragt am: 22. 02. 2020].

15. NETDOKTOR (2020) Viagra (28.02.2020), https://www.netdoktor.de/medikamente/viagra/ [abgefragt am 28.02.2020].

16. TOTZT S (2010): Campaign: Kitkat - sweets with a bitter aftertaste. (31.03.2010), http:// www.greenpeace.de/themen/waelder/nachric hten/artikel/kitkat_suesses_mit_bitterem_bei geschmack-1/ [abgefragt am 22.02.2020]. 